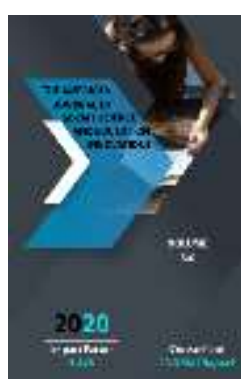

Journal Website: http://usajournalshub.c om/index,php/tajssei

Copyright: Original content from this work may be used under the terms of the creative commons attributes 4.0 licence.

\section{Duties Of Professor-Teachers In The Credit-Module System}

\author{
Nosirova Dilnoza Toir Qizi \\ Teacher At The Jizzakh State Pedagogical Institute, Uzbekistan \\ Kamolova Aziza Pardaboyevna \\ Teacher At The Jizzakh State Pedagogical Institute, Uzbekistan \\ Qazibekov Musaxon Qudratillayevich \\ Teacher At The Jizzakh State Pedagogical Institute, Uzbekistan
}

\title{
ABSTRACT
}

This article discusses the role and importance of the credit-module system in higher education; priorities; It is scientifically and methodologically substantiated that one of the positive aspects of the credit system is the organization of teaching on the basis of credit-module system in the development of knowledge, skills, abilities and competencies of students.

\section{KEYWORDS}

Credit - modular system, module, modular teaching technology, credit teaching technology, the main functions of the credit-modular system in higher education institutions, the functions of professors and teachers in the credit-modular system.

\section{INTRODUCTION}

Since the second half of the twentieth century, as in all areas, practical efforts have been made in the higher education system to achieve international cooperation, to develop a unified approach to the training of highly educated, qualified personnel.

Today, the main task of the higher education system is to train qualified specialists. In order to train such a specialist, of course, it is necessary to determine the system of requirements for him. In search of an answer to this question, we came across a system of requirements in the following four areas:

1. To have the necessary knowledge, skills and competencies in their field.

2. Continuous improvement of existing knowledge in the field, ie readiness for independent learning. 
3. Ability to research and create independently to innovate in the field.

4. Ability to plan, manage and organize their time.

The effectiveness of the education system is directly ensured by the level of teachers, student needs, the content of textbooks and the infrastructure aimed at the formation of independent learning. This means that the training of advanced personnel, increasing their competitiveness in accordance with the requirements of the labor market, the development of creative thinking professionals are closely linked with the educational process in educational institutions.

President signed Decree No. PF-5847 of October 8, 2019 "On approval of the Concept of development of the higher education system of the Republic of Uzbekistan until 2030". This important policy document states that "at least 10 higher education institutions in the country should be included in the list of the top 1000 higher education institutions in the ranking of internationally recognized organizations (Quacquarelli Symonds Worlds University Rankings, Times Higher education or Academic Ranking of World Universities). "Transition to a phased credit-module system".

The concept also sets the task of "gradual transition of the educational process in higher education institutions to a credit-module system." It is also planned to increase the number of universities with a credit-module system from 2 to 85 . The number of nongovernmental, public-private partnership higher education institutions will be increased to 35. In addition, the decree also emphasizes the need to replace theory with practical skills. Now we have up to 40 percent of education allocated for independent study, but according to the concept, this figure will increase to 60 percent by 2030 .

The credit-module system is the most advanced form of modern education. According to the credit-module system, training is based on person-centered learning technologies and independent student learning.

The purpose of modular education is to form the knowledge, skills and abilities of students in the field. In modular education, the teacher organizes, directs, advises, checks the process of mastering the listener. The student, on the other hand, moves independently toward the oriented object. The greatest emphasis is also placed on students 'independent learning.

What are the main functions of the credit module?

Experts on a number of social networks have expressed clear views and conclusions in this regard. That is, the main functions of the creditmodule system are as follows:

a) Modular organization of educational processes;

b) Determine the value of a single subject, course (credit);

c) Assessment of students' knowledge on the basis of rating points;

d) Enabling students to create their own curricula individually;

e) Increasing the share of independent learning in the educational process;

f) The convenience of training programs and the possibility of change depending on the demand for specialists in the labor market.

In addition to conducting lessons on the basis of innovative educational technologies, professors and teachers of higher education institutions teach each student to study independently, to take a new approach to education, to acquire the necessary and indepth theoretical knowledge and practical skills based on labor market demand.

The teacher organizes the learning process, gives live, video and audio lectures, and focuses on how well the student is learning. They also regularly organized effective events such as a master class, seminar-training and online consultation on the social Telegram 
channel on the implementation of the new credit-module system. Professors are responsible for the preparation and delivery of teaching materials in their subjects, as well as for the student to search, process and master these materials and additional information on the relevant topic in the classroom and in independent study. In turn, in the creditmodule system, experienced professors will be able to present interesting information on new topics on the basis of modern innovative technologies. In particular, in the formation of the curriculum of the credit-module system of higher education, special attention is paid to the acquisition of practical skills in the specialty, as well as the achievement of quality indicators by mastering the content of disciplines.

According to the credit-module system, the responsibilities of teachers in the educational process are clearly defined. According to him, the duties of a teacher are:

1. A teacher may act as a speaker, tutor, advisor or member of special boards, depending on his / her functional duties.

2. Active participation in teaching, methodological and research work, as well as in social life, the promotion of values accepted in this community and strengthening the position of the institute in the market of educational services is the main activity of the teaching staff.

3. A 36-hour weekly workload of a teacher can be divided into the following main types:

- Work related to teaching and quality preparation for it;

- Creation of educational and methodical complex of science;

- Advise the student;

- Self-study and research activities;

- Academic management (decan, heads of departments)
4. Qualified teachers who can conduct lectures at a high scientific and methodological level are appointed as speakers.

5. The right to teach lectures in the academic year, according to the decision of the council of the institute, can be given to experienced and highly qualified teachers who do not have an academic degree.

The responsibilities of tutors and advisors include:

The tutor supervises each student's learning process, evaluates the completion of individual assignments, seminars, practical and laboratory classes, and assists him or her as needed.

Adviser represents the interests of the student in the learning process, participates in the preparation of the necessary information materials on the learning process and provides these materials to the student in electronic form, monitors the availability of timely training and methodological materials, intermediate and final examinations in all disciplines.

Adviser is appointed by the rector of the institute. During the academic year, advisors work according to a plan approved by the dean's office. The advisor may arrange unscheduled meetings to address students 'academic concerns.

Advisor activities include:

- Acquaints students with the rules of organization of the educational process;

- Determine the priorities, abilities and capabilities of students;

- Introduction to the standard curriculum and catalog of elective subjects;

- Explanation of the number of test units and their development;

- Organization of various public committees aimed at the effective organization of the educational process at the institute. 
The study and analysis of the introduction of the credit-module system in education shows that it has its own characteristics in different countries of the world. The expediency and effectiveness of the credit-module system in education is reflected in the widespread use of the education system in many countries, as the development of educational programs allows students to independently acquire knowledge and increase the level of creative activity, which increases student competence. This means that the quality of education will increase completely.

The introduction of this system in higher education will improve the quality of teaching, ensure transparency, eliminate corruption, reveal the true knowledge of the student and create the basis for students to study and work independently.

The introduction of a credit-module system is an important factor in the collaboration of teachers and students. The importance of independent learning in the learning process will increase, which will lead to an increase in the independence, creative initiative and activity of professionals in the future. In the credit-module system, students of the institute always have the opportunity to receive help and advice from teachers and classmates. This strengthens mutual understanding and builds teamwork skills.

The transition to a credit-modular education system will also increase the commitment and demand for university professors. As mentioned above, with a modular learning system, the teacher performs not only informational and supervisory functions, but also advisory and coordinating functions. The leading role of the teacher in the pedagogical process is preserved.

In short, such a system, in terms of the idea and methodology of education, allows the student to form the skills and abilities of interpersonal relationships throughout his life from the student period. It provides a basis for the graduate to draw his / her own conclusions about his / her self-confidence, his / her capabilities, abilities and readiness for professional competence as a ready staff.

\section{REFERENCES}

1. Decree of the President of the Republic of Uzbekistan dated October 8, 2019 No. PF5847. The concept of development of the higher education system of the Republic of Uzbekistan until 2030. p.2.

2. Izyetayeva G.K. Credit technology of teaching - mathematics education

as a factor of development. Republican scientific-practical conference on "Actual problems of mathematics and its teaching", Andijan - November 8-9, 2011, pp. 149-151.

3. Muslimov N.A., Koysinov O.A. "Organization of independent education in the training of teachers of vocational education" - Tashkent State Pedagogical University, Tashkent 2006

4. Mustafaqulov Sh., Sultonov M. "Why switch to a credit system?" People's Word newspaper. 2020 y. August 5th

5. Nosirova M., Khummamatova K., Nosirova D. The essence and significance of the credit-module system. Modern problems of differential equations and related branches of mathematics. International scientific conference.II. Fergana 2020.

6. Nosirova M., Xummamatova K., Nosirova D. "Organization of credit education in pedagogical universities." "Modernization of teaching specific sciences: new models and practices of innovative education." Collection of materials of the republican scientific online conference. Tashkent-2020.

7. Nosirova M., Nosirova D. "The importance of independent work of students in a modular credit system". Competence approach to education: problems and solutions. Proceedings of the Republican online scientific-practical conference I. Andijan 2020. 
8. Nosirova M., Nosirova D., Kubaeva L. "Teaching on the basis of credit technology - as a factor in increasing student competence." Competency approach to education: problems and solutions. Proceedings of the Republican online scientific-practical conference I. Andijan 2020.

9. Tishchenko, E.A. Implementation and prospects for the development of credit units in the learning process SRSTU (NPI) [Text]. EA Tishchenko // Innovative educational technologies in technical universities Collection of scientific articles on the problems of higher education Novocherkassk Publishing house YRSTU (NPI) - $2006-0.25 \mathrm{p}$.

10. Tishchenko, E.A. Organization of a credit education system at a technical university. Abstract. Candidate of Pedagogical Sciences: 25.10.2007 Rostov-on-Don, 2007. 21st.

11. Yunusova D.I., Rakhmonov I.Y. "Scientific and theoretical bases of development of methodical training of the future teacher of mathematics". Toshkent.2018.-16ob.

12. Urinov V. ECTS credit-module system in higher education institutions of the Republic of Uzbekistan: basic concepts and rules. 10.08.2020

13. European Commission ECTS Guide of 2015. Available at https://ec.europa.eu/education/ects/usersguide/docs/ects-users-guide_en.pdf 